\title{
COL4A3BP wt Allele
}

National Cancer Institute

\section{Source}

National Cancer Institute. COL4A3BP wt Allele. NCI Thesaurus. Code C90608.

Human COL4A3BP wild-type allele is located in the vicinity of $5 q 13.3$ and is approximately $141 \mathrm{~kb}$ in length. This allele, which encodes collagen type IV alpha-3-binding protein, may be involved in the regulation of ceramide trafficking. 